\title{
Jolanta Kowalewska-Dąbrowska \\ Tekst poetycki jako przedmiot badań lingwistycznych. Teoria i praktyka w kontekście semantycznych interpretacji utworów poetyckich Janusza Pasierba oraz Anny Kamieńskiej Pelpin 2013, ss. 208
}

Książka Jolanty Kowalewskiej-Dąbrowskiej wpisuje się w nurt studiów nad semantyką utworu artystycznego. Jest to pozycja cenna, potwierdzająca nie tylko ważną rolę językoznawców w badaniach tekstów poetyckich, ale też eksponująca wzajemne korzyści wynikające z konfrontacji współczesnych metod badawczych właściwych literaturoznawstwu i lingwistyce. Oddajmy głos Autorce:

„Ogólnie rzecz biorąc, lingwiści nurtu kulturowego podkreślają zasadność stosowania wieloparadygmatyczności i interdysplinarności we współczesnej lingwistyce (a także w innych dyscyplinach humanistyki).

We współczesnych badaniach tekstów artystycznych dokonywanych przez lingwistów przyjmuje się różne perspektywy badawcze: tekstologiczną, stylistyczną, genologiczną, semantyczną czy pragmatyczną, ale wspólne jest dla nich założenie, że każdy utwór jest zdeterminowany gatunkowo i stylowo, jest tekstem czyimś i dla kogoś. Natomiast wybór którejś z perspektyw opisu jako centralnej (lub wyjściowej) nie oznacza pozostawienia na boku pozostałych, lecz służy jedynie uwypukleniu dla celów badawczych wybranych aspektów wypowiedzi artystycznej" (s. 11).

Jolanta Kowalewska-Dąbrowska podejmuje próbę zweryfikowania możliwości stosowania różnych lingwistycznych metod badania utworów poetyckich, a w konsekwencji sprawdzenia, w jaki sposób owe metody służą wydobywaniu bogactwa znaczeniowego słów i jak pomagają w interpretacji tekstu kreatywnego. Za podstawę swoich rozważań badaczka przyjmuje teksty Anny Kamieńskiej i Janusza Stanisława Pasierba, którzy 
poruszają w swoich utworach problemy egzystencjalne, w tym przede wszystkim koncentrują się na relacji między życiem a śmiercią.

Książka składa się z trzech rozdziałów, których zawartość oraz układ chronologiczny w sposób jasny, uporządkowany i czytelny dowodzi konsekwencji Autorki w realizacji wyznaczonego celu badawczego poprzez przyjęcie perspektywy metodologicznej charakterystycznej dla współczesnej semantyki kulturowej.

Rozdział I Metodologie lingwistyczne jako narzędzie badań tekstów artystycznych jest bardzo rzetelnym przeglądem stanu badań nad wskazanym $\mathrm{w}$ podtytule zagadnieniem. Rzeczowa retrospektywa - można by rzec, paradoksalnie - łączy w sobie dwie sprzeczne postawy: obiektywizm opisu stanu badań z krytyczną wnikliwością Autorki wobec niektórych postaw badawczych. Jolanta Kowalewska-Dąbrowska, powołując się zarówno na literaturoznawców, jak i lingwistów, eksponuje rozumienie literatury jako językowego dzieła sztuki oraz tekstu kultury, zwraca przy tym uwagę na interdyscyplinarność i poliparadygmatyzm współczesnego językoznawstwa:

„Na styku tego rodzaju pytań i wątpliwości związanych z ustaleniem ogólnego przedmiotu badań można zauważyć tendencję zbliżania stanowisk literaturoznawców i językoznawców w dziedzinie niektórych subdyscyplin w związku z poszerzaniem pola badawczego i stosowaniem zasady wieloparadygmatyzmu. Widać to na przykładzie kierunku rozwoju stylistyki współczesnej, która coraz wyraźniej staje się dyscypliną, bez podziału na stylistykę literaturoznawczą i stylistykę językoznawczą" (s. 15).

W rozdziale tym znajdujemy ponadto szczegółowy komentarz dotyczący teorii kognitywnych oraz teorii semantyki kulturowej w badaniach utworów poetyckich, przy jednoczesnym zastrzeżeniu, że jednoznaczne rozdzielenie owych teorii nie jest możliwe, gdyż w większości prac ich autorzy łączą kilka paradygmatów badawczych wywodzących się z kognitywizmu.

Badaczka próbuje $\mathrm{w}$ tym miejscu odpowiedzieć też na pytanie, dlaczego lingwiści w badaniach semantycznych tak chętnie sięgają do tekstów poetyckich.

Rozdział II Język wobec podstawowych wymiarów ludzkiego życia i śmierci przedstawia językowo-kulturowy obraz CZASU i PRZESTRZENI oraz obraz ŻYCIA i ŚMIERCI w polszczyźnie. Uwagę zwraca rzetelność opisu, wielość kontekstów badawczych i różnorodność analizowanych źródeł. Autorka przywołuje opracowania i teorie filozoficzne, literaturoznawcze 
oraz językoznawcze poświęcone interpretacji wskazanych pojęć, także zróżnicowane chronologicznie i semantycznie definicje słownikowe oraz z rozmysłem wyselekcjonowane teksty literackie. Na tej podstawie buduje klarowny, solidny przekaz naukowy, daleki od wszelkiej powierzchowności czy przesadni, pokazujący relacje między pojęciami życia, śmierci, czasu i przestrzeni w kulturze polskiej (i szerzej: europejskiej) na przestrzeni wieków.

Rozdział III Poeci o sprawach ludzkiej egzystencji. Kreacje życia i śmierci $w$ wierszach Janusza Pasierba i Anny Kamieńskiej stanowi zasadniczy trzon pracy. Autorka z dużą wnikliwością i wrażliwością estetyczno-lingwistyczną odtwarza poetyckie profile ŻYCIA i ŚMIERCI w twórczości obojga poetów. Swoje szczegółowe rozważania skupia wokół metaforycznie ujętych zagadnień: Życie w ciagłym ruchu, Skąd i dokąd wędrujemy, Przez czas do celu wędrówki, Śmierć jest ciągle z nami, Metafora SNU.

Analiza została przeprowadzona wnikliwie, zgodnie z teorią i metodologią badań językowego obrazu świata, i jak pisze sama Autorka, "dostosowaną do badania indywidualnych (podmiotowych) wariantów tego obrazu, w powiązaniu z wybranymi aspektami teorii kognitywnych, głównie modelem sieciowym Langackera i teorią metafor pojęciowych Lakoffa i Johnsona" (s. 72). Tak przeprowadzone interpretacje tekstów kreatywnych pokazały zarówno cechy wspólne dla obojga twórców, jak też cechy wyraźnie oba nurty twórczości różniące. Autorka jasno pokazuje, że o podobieństwach decydują wspólne, kulturowo utrwalone „wzorce pojęciowe (profile kulturowe), do których odnoszą się zrekonstruowane profile tekstowe (i idiolektalne), natomiast zindywidualizowane są często wybory różnych komponentów modeli kognitywnych eksponowanych w poszczególnych tekstach i oczywiście zróżnicowany jest też kształt stylistyczny utworów, indywidualne sposoby wykorzystania potencji językowej" (s. 72). Oboje artyści choćby - jak wynika - z przeprowadzonej analizy konceptualizują ŻYCIE JAKO DROGĘ//PODRÓŻ DO BOGA. Takiej interpretacji przypisać można 'przemijalność', 'nietrwałość', 'czasowość' (cechy obiektywne) oraz 'uciążliwość', 'konieczność ustawicznego wysiłku', 'cierpienie i rozpacz' (cechy subiektywne, konotowane poprzez wymiar osobistych przeżyć artysty). Konceptualizowanie ŚMIERCI w twórczości Pasierba i Kamieńskiej również opiera się na modelu PODRÓŻY, ale tym razem jest to PODRÓŻ do kresu życia ziemskiego, którego początkiem staje się życie wieczne. W poetyckich profilach ŚMIERCI badaczka wyróżnia - wspólne dla obojga artystów - cechy obiektywne 
('nieuchronność', 'nieznany czas' - życie zawsze kończy się śmiercią, ale nie wiadomo, kiedy to nastąpi) oraz subiektywne, związane $z$ różnorodną waloryzacją ŚMIERCI (z jednej strony: lęk, przerażenie, niepokój; z drugiej: nadzieja i tęsknota za spotkaniem z Chrystusem). Różnice zaś między profilami ŻYCIA i ŚMIERCI w badanej poezji „polegają na tym, że $\mathrm{w}$ idiolekcie każdego z poetów wysuwane są na plan pierwszy inne komponenty metafory PODRÓŻY. Janusz Pasierb chętnie podkreśla fakt samej wędrówki, czego wyrazem jest stosowanie dużej liczby czasowników ruchu. Z kolei Kamieńska więcej uwagi poświęca charakterystyce obu przestrzeni, między którymi przebiega podróż życia" (s. 167). Do różnic Jolanta Kowalewska-Dąbrowska zalicza również swoistość leksyki tekstów obojga artystów, a także złożoną odmienność stylistyczną badanych utworów.

W krótkiej recenzji trudno uwzględnić wszystkie aspekty badawcze podnoszone w recenzowanej rozprawie. Niewątpliwie jednak Jolancie Kowalewskiej-Dąbrowskiej udało się zrealizować zakładane cele dzięki sprawnemu wykorzystaniu teorii językowego obrazu świat. Kontekstualność językowa i kontekstualność pozajęzykowa ${ }^{1}$, a także interdyscyplinarność metodologiczna sprawiają, że otrzymujemy kolejny już, sumiennie przygotowany tekst naukowy Autorki.

Należy podkreślić, że jest to książka napisana ze smakiem i badawczą pasją. Nie mam najmniejszych wątpliwości, że stanie się ona na polskim rynku wydawniczym pozycją, której - ze względu na walory intelektualne - nie sposób pominąć.

Urszula Sokólska

Uniwersytet w Białymstoku

1 Kontekstualność językową Autorka rozpatruje w płaszczyźnie najbliższego otoczenia słowa i w płaszczyźnie całego wiersza; kontekstualność pozajęzykową wiąże z czynnikami ogólnokulturowymi, wspólnymi dla określonej wspólnoty kulturowej bądź kulturowymi czynnikami zindywidualizowanymi, uzależnionymi od elementów biograficzno-światopoglądowych. 